JOURNAL OF SECURITY AND SUSTAINABILITY ISSUES

ISSN 2029-7017 print/ISSN 2029-7025 online

2019 March Volume 8 Number 3

http://doi.org/10.9770/jssi.2019.8.3(16)

\title{
Scopus
}

\section{TAX SECURITY OF NATIONAL ECONOMIC SYSTEMS IN GLOBALIZATION CONDITIONS}

\author{
Tetiana Kosova $^{1}$, Iryna Steblianko ${ }^{2}$, Nataliya Slobodyanyuk ${ }^{3}$, Vadym Doroshkevych ${ }^{4}$ \\ ${ }^{1,3}$ Donetsk National University of Economics and Trade named after Mykhaylo Tugan-Baranovskiy, \\ 16 Ostrowski, Kryvyi Rih, 50005 Ukraine \\ 2,4 Oles Honchar Dnipro National University, 72 Gagarina, Dnipro, 49000 Ukraine
}

E-mails: ${ }^{1}$ kosovatd@meta.ua; ${ }^{2}$ irinasteb23@gmail.com, ${ }^{3}$ slobnata21@gmail.com, ${ }^{40003997 @ g m a i l . c o m ~}$

Received 18 November 2017; accepted 5 December 2018; published 30 March 2019

\begin{abstract}
The theoretical and methodological principles of researching the tax security of a state were substantiated with the emphasis placed on the two basic economic theories: the social choice theory and the reflectivity theory. The differential features of national tax systems under globalization conditions and their impact on the economic security of the countries that differ in the political regime, the level of economic development, geography and location were identified. There was given the assessment of the cross-sector approach, based on which multifactor effective marginal tax rates in the European Union (EU) are calculated, and of the marginal approach to taxation in general. The analytical study of tax security of the countries of Organization of economic cooperation and development (OECD) was carried out based on the assessment of the specific weight of taxes in gross domestic product, as well as the structure of taxes in the context of taxation objects: income individuals, income corporates, social security contributions, property, value added taxes, other consumption taxes. A particular attention is attached to the problems of taxation of the motion of capital and goods between the EU countries within the framework of ensuring the mutual economic benefits of the collective interests. The assessment of external and internal threats to tax security of Ukraine was performed based on the identification of the shadow economy segment, reasons for its emergence and consequences for the national economy, as well as the dynamics of the absolute and relative indicators of the budget-debt security. The recommendations on strengthening the tax security of Ukraine under the European integration conditions were given.
\end{abstract}

Keywords: tax, economic, national, security, system, globalization

Reference to this paper should be made as follows: Kosova, T; Steblianko, I; Slobodyanyuk, N; Doroshkevych, V. 2019. Tax security of national economic systems in globalization conditions, Journal of Security and Sustainable Issues 8(3): 493-505.

http://doi.org/10.9770/jssi.2019.8.3(16)

JEL Classifications: F15, F52, F65, E62, H21, O11

Additional disciplines: law, sociology

\section{Introduction}

The national security is the most important benefit, provided by the legal system, electoral process, constitutional economy, and so on. In this context, taxation should be considered in two dimensions, i.e. legal and economic: the synthesis of these two components reveals its essence and significance in terms of the national security. The role of the tax security for the development of the national economy grows under conditions of the transformation processes, which are accompanied by the variability of the environment of taxpayers, including instability of the legal regulation of their activities, deterioration of the financial state of economic entities, reduction of the tax base and the range of taxation entities. The emergence of threats to the tax security may affect not only the budget deficit, but also have cumulative effects associated with the increasing risks of deterioration of the state of the national security components. 


\section{Literature review}

Taxes take a special place in the economic security system, because they not only provide financial resources for almost all components of the economic security (financial, social, environmental, legal, etc.), but also act as the tool of influence on economic and social processes and the factor of feedback and dependence of state functioning on taxpayers (Onyshko et al. 2004; Tvaronavičienè, Gatautis 2017; Vandina, et al. 2018; Fabuš, Csabay, 2018).

Some authors have proposed the progressive scale of taxes, solidarity taxes and other measures to provide security (Menshikov et al. 2017).

\section{Theoretical and methodological principles of researching tax security}

Taxation is the basis for the sustainable development, it supports the functions of effective state administration and creates the conditions for economic growth (Prichard 2010). Full implementation of taxation functions involves a responsible activity of the government, its accountability to the society. One of the purposes of taxes is funding the social benefits. The public choice theory is of primary importance for the interpretation of the tax security of the state, since it studies the issues of taxation and public spending in the context of providing the shared benefits. The material basis of the economic security is the national wealth, which is accumulated by collection of the part of social benefits in the form of taxes. Consequently, provision of their receipt in sufficient quantities is the economic basis of existence of the state, and of social development, while the rules and standards of the taxation system determine the institutional guidelines for the development of the institutions in the domain of economic safety (Ball 2014; Tarasova et al. 2018).

Tax administration acts as an important tool of filling the revenue part of the budget, which funds the costs of the execution of the state administration functions, as well as provides the resources for other components of national security: the military-political, economic, financial, innovative-investment, eco-agricultural etc.

Depending on the state of the development of the tax system of a country and the general macroeconomic state, it is possible to separate two approaches to the interpretation of tax security: the resource approach - the ability to tax part of the budget to fund the needs of the support of national security at the determined level (is guaranteed by sustainability and sufficient amount of tax revenues, budget surplus, existence of reserve funds); the risk approach - increased threats to national security (is manifested in the reduction of tax revenues to the budget, the failure to attain the planned indicators of taxes accumulation, budget deficit and existence of expenditure articles associated with the service of credit lines, bonds of internal and external debt, etc.).

From the point of view of the reflectivity theory, tax security can be defined as a cognitive (passive) and influence (active) function (Soros 2015). Reflectivity is described by the pair of recursive functions:

$$
\begin{aligned}
& y=f(x) \text { cognitive function } \\
& x=\varphi(y) \text { influence function }
\end{aligned}
$$

Thus

$$
\begin{aligned}
& \mathrm{y}=\mathrm{f}[\varphi(\mathrm{y})] \\
& \mathrm{x}=\varphi[\mathrm{f}(\mathrm{x})]
\end{aligned}
$$

The influence function of the tax security is associated with the provision of members of the society with the benefits of collective use by the state, with ensuring the state support of priority industries of the national economy, the implementation of socio-economic programs, etc. In the influence function, the dynamics and the amount of tax revenue to the budget affects the state and the development of macroeconomic processes. In the cognitive function, the tax provision of national security is the function of its separate components tax security of separate national economy entities. The separated recursive functions operate in the opposite directions: in the influence function, the economic security of a state is a factor, and in the cognitive function - 
it is a resulting indicator. The interaction of the separated recursive functions leads not to the balance, but rather to the process of endless changes. For example, the requirements for the provision of tax security under conditions of the budget deficit by means of attracting external loans increase the risks of the debt insecurity of the state and determine the need for an increase in the tax revenue of the budget for their repayment with the interest in future. Often taxation is considered as a restriction to any market development, lessening the willingness to effective actions or raising the opportunity costs. Therefore lots of investigations are dedicated to identification of optimal measures in order to satisfy the fiscal needs still encouraging market performance (Astrauskaite et al. 2016).

Tax security is a complex and multifaceted phenomenon, which manifests itself at different hierarchical levels. Security tax components of the national economy are: tax security of the state budget; tax security of local budgets; tax security of regions; tax security of economic entities; tax security of households; tax security of the institutional environment of enterprise functioning, which has to ensure the sustainability of the legal regulation and the uniform tax burden. All tax security components are in a close dialectic relation. They are different in entities, but apart from them, the term "tax security" can be defined as a state of tax relations, characterized by sustainability and stability of object parameters and implies the ability of entities to protect their economic interests, to confront external and internal threats, to implement and develop the tax potential, to use the competitive advantages of the tax system under the globalization conditions (Petrenko 2012).

\section{Differential features of national tax systems and their impact on economic security}

The differential features of national tax systems are determined by many factors, which include: the sociopolitical formation, the trajectory of institutional development, the level of openness of the national economy, the state of budget-debt relations, the mechanisms of interaction between the financial and the actual sectors of economy. The construction of the tax system is essentially influenced by the type of the political regime, but there is no unambiguous conclusion about the consequences of the democratic or authoritarian nature of the statehood on the taxation level.

The paper of Garcia et al. (2016) deals with studying the relations between political regimes and the ratio of tax indicator to gross domestic product based on the data of 131 countries of the world within 1990-2008. It was concluded that democratic regimes contribute to increasing taxation effectiveness, but there is no linear tendency.

The method of income taxation in different countries becomes a significant factor of the international tax competition, even in countries that formerly comprised the whole. It is illustrated by the case of Czechoslovakiain Slovakia, there is a tendency to find and develop more effective income taxation methods, to construct a socially fair and at the same time less costly tax system. Dobrovič et al. (2017) refer to the importance to strengthen the battle against tax frauds and tax evasions in Slovakia and the aim is to point out the current tax collection and the overall tax administration in the Slovak Republic with the focus on value added tax (VAT). The Czech Republic is more conservative and does not resort to sudden radical changes, implementing iterative reforms (Lipkova et al. 2017). The aim of the article of Paseková et al. (2018) is to evaluate how information about deferred tax is reported by small and medium sized enterprises in Czech Republic and evaluate quality of such reporting. The research was conducted in the form of a questionnaire survey concerning recognition of deferred tax among accounting units which prepare their financial statements according to IFRS or according to Czech accounting standards. The research clearly showed the unwillingness of accounting entities to recognize deferred tax voluntarily.

There is a cautious attitude to marginal reforms in the world practice, because there are political and economic restrictions on major reforms of direct (or indirect) taxation (Sevryukova et al. 2016), the emphasis is placed on the need to perform not only the fiscal but also the social function by a tax. According to the survey of respondents-taxpayers, one may trace a strong effect of the own interest in tax relations, since in Sweden, the most unpopular tax is the real estate tax and the least unpopular - the corporative tax (Hammar et al. 2009). 
In foreign countries, there are significant differences in the law on organization of taxation of economic entities. The Korean income tax does not require a consolidated tax return, and business groups with lots of branches have some stimuli to redistribute the income between member companies to reduce general taxes of the group (Jung et al. 2009). So, there are certain features of the behavior of affiliated firms in Korean business groups. Progressive changes in the taxation system in Vietnam are: replacement of the turnover tax with the value added tax. Regressive changes include a minor role of profit tax of enterprises because much of the gross domestic product is produced and consumed by households, the activities of which are not taxed; cancellation of the agricultural farming tax; uneven distribution of agricultural subsidies between rich and poor households.

Analyzing the Australian tax system, Jun et al. (2011) say that the creation of institutional funds of shares (domestic analogues are institutions of collective investment) has tax advantages over the shares, by which the dividends taxed by the income tax of an enterprise are paid. Taxes are accumulated as a result of the activity of a formal sector of the national economy. Zimbabwe, like most developing countries, faces the problems of imposing taxes on the informal sector, specifically: corruption, quasivoluntary compliance with and selective application of tax regulations by its entities (Dube 2014).

Cluster analysis allowed the authors to determine that agreement of tax policies in the European Union still remains at the insufficient level, therefore, there is a need for further harmonization of the actions of separate states in the tax sphere (Mihokova et al. 2016). A description of the measures regarding exogenous changes in the marginal tax rates, related to the tax reforms in the United States, allowed determining the tax elasticity at the level of 1.2. A decrease in the marginal level to $1 \%$ leads to an increase in actual GDP growth and a decrease in the unemployment rate (Mertens et al. 2018). Important information for the analysis of the effectiveness of tax systems is provided by national calculations. Researchers from the United States offer to apply distributive national calculations (Piketty et al. 2018), which can be used for consistent comparison of the income between countries, as well as for assessment of the level of fiscal decentralization (in case of their implementation at the state and the local levels).

In the countries with the imperfect market, the needs of provision of economic independence require monitoring conditional and unconditional amounts of the state debt, tax revenues, estimation of the dispersion of invariant distribution, as well as the average reversion rate. For the conditions of the United States, it was found that an optimal level of debt by the target index is negative or close to zero, the invariant debt distribution is very scattered, and the average reversion is insignificant (BhaEvans et al. 2017). This indicates a sufficient level of the tax-debt security of the state. Taxation changes of EGTRRA (Economic Growth and Tax Relief Reconciliation Act, 2001, 2003) have a considerable impact on the development of the economy of the United States. The Act introduced significant changes to the Tax Code of the United States in the part of the income tax rates, including that on property and gifts, reduction of duties for individual pension insurance. The original motivation for its adopting was focusing on a decrease in the state debt of the United States (Heim et al. 2008).

Guaranteeing the country's tax security requires taking into account the tendencies of development of information technologies; the development of the rules of taxation of Internet transactions, e-commerce; the use of electronic documents circulation for the tax administration (Nellen 2012). The competitiveness of Internet shops is based on the elasticity of prices. E-commerce may be significantly reduced, if the sale of goods in the Internet is taxed.

\section{Analytical research into tax security of OECD countries}

Institutional features of the national tax codes and international interaction between them leads to emergence of complex financial instruments, determines the need for their unification, harmonization, as well as the international tax planning. In the OECD countries, the unified structure of the tax system, which includes taxes for capital, labor and energy is used (Barrios et al. 2018). Assessment of their tax security is carried out using the generally accessible information regarding the most important indicators of the effectiveness of tax policy of a state (Afanasyeva et al.2016). 
The basis for the creation of the system of collective tax security of the OECD countries is the inter-sector approach and calculation of multifactor effective marginal tax rates (EMTR). The contribution of the input factors to the effective tax, which is collected from the companies-taxpayers is calculated taking into account the substitution degree, the tax share and the profitability rate. The most important factor of the effective tax rate is the taxation of labor, capital investment, and corporate earnings. Marginal tax burden on investment projects is determined by comparing their value before and after capital taxation. The traditional measures of the effective marginal taxation additionally imply the perfect competition. So they ignore the ability of companies to set prices that exceed the marginal production costs, including taxes. This implicit assumption contradicts the existing evidence of the ability of multinational companies to generate profits after taxation. It the competition is imperfect, the companies can set a positive markup to their final price, and this markup can vary essentially between the companies and production sectors. Such elimination can be the result of the assumption about lossfree investments for the calculation of effective marginal tax rates for capital investments.

The summary of key tax revenue ratios in the OECD is presented in Table 1 . The OECD countries differ considerably by the tax share in the GDP, the variation span is from $30,0 \%$ in 2017 to $37,5 \%$ in 2000 . The following countries have the highest specific weight - Iceland $(51,6 \%, 2016)$, Sweden $(49,0 \%, 2000)$, France $(46,2 \%, 2017)$, Denmark $(46,1 \%, 2015)$, while Mexico has the lowest (within the entire studied period the specific weight of the country increased from $11,5 \%$ to $16,6 \%$ ).

Table 1. Summary of key tax revenue ratios in the OECD

\begin{tabular}{|c|c|c|c|c|c|c|c|c|c|c|c|}
\hline \multirow[b]{2}{*}{ Country } & \multicolumn{4}{|c|}{ Tax revenue as $\%$ of GDP } & \multicolumn{7}{|c|}{ Tax revenue as \% of total tax revenue in 2016} \\
\hline & 2017 & 2016 & 2015 & 2000 & $\begin{array}{l}\text { Taxes on } \\
\text { income, } \\
\text { individuals } \\
(\mathrm{PIT})\end{array}$ & $\begin{array}{l}\text { Taxes on } \\
\text { income, } \\
\text { corporates } \\
\text { (CIT) }\end{array}$ & $\begin{array}{c}\text { Social } \\
\text { security } \\
\text { contributions } \\
(\mathrm{SSC})\end{array}$ & $\begin{array}{l}\text { Taxes on } \\
\text { property }\end{array}$ & $\begin{array}{l}\text { Value } \\
\text { added } \\
\text { taxes }\end{array}$ & $\begin{array}{c}\text { Other } \\
\text { consumption } \\
\text { taxes }\end{array}$ & $\begin{array}{l}\text { All } \\
\text { other } \\
\text { taxes }\end{array}$ \\
\hline OECD-average & 34,2 & 34,0 & 33,7 & 33,8 & 23,8 & 9,0 & 26,2 & 5,7 & 20,2 & 12,5 & 2,6 \\
\hline Australia & - & 27,8 & 27,9 & 30,5 & 40,8 & 16,5 & 0,0 & 10,8 & 12,9 & 14,2 & 4,9 \\
\hline Austria & 41,8 & 42,2 & 43,1 & 42,3 & 21,6 & 5,6 & 34,7 & 1,3 & 18,3 & 10,0 & 8,5 \\
\hline Belgium & 44,6 & 44,1 & 44,8 & 43,5 & 27,7 & 7,8 & 31,1 & 8,0 & 15,4 & 9,1 & 0,9 \\
\hline Canada & 32,2 & 32,7 & 32,7 & 34,8 & 36,3 & 10,5 & 14,9 & 12,0 & 13,5 & 9,7 & 3,2 \\
\hline Chile & 20,2 & 20,2 & 20,4 & 18,8 & 8,8 & 20,9 & 7,2 & 5,1 & 41,2 & 13,4 & 3,5 \\
\hline Czech Republic & 34,9 & 34,2 & 33,3 & 32,4 & 11,2 & 11,0 & 42,9 & 1,4 & 21,7 & 11,3 & 0,5 \\
\hline Denmark & 46,0 & 46,2 & 46,1 & 46,9 & 53,5 & 5,8 & 0,1 & 4,0 & 20,4 & 11,6 & 4,5 \\
\hline Estonia & 33,0 & 33,7 & 33,3 & 31,1 & 17,2 & 5,0 & 33,2 & 0,8 & 27,0 & 16,3 & 0,5 \\
\hline Finland & 43,3 & 44,0 & 43,9 & 45,8 & 29,6 & 5,0 & 29,1 & 3,2 & 20,7 & 12,1 & 0,3 \\
\hline France & 46,2 & 45,5 & 45,3 & 43,4 & 18,8 & 4,5 & 36,8 & 9,4 & 15,2 & 9,2 & 6,2 \\
\hline Germany & 37,5 & 37,4 & 37,0 & 36,2 & 26,6 & 5,2 & 37,6 & 2,8 & 18,5 & 8,6 & 0,6 \\
\hline Greece & 39,4 & 38,8 & 36,6 & 33,4 & 15,2 & 6,5 & 28,5 & 8,1 & 21,2 & 18,4 & 2,1 \\
\hline Hungary & 37,7 & 39,2 & 38,7 & 38,5 & 13,3 & 6,0 & 33,2 & 2,8 & 23,7 & 18,6 & 2,3 \\
\hline Iceland & 37,7 & 51,6 & 36,3 & 36,3 & 26,7 & 4,9 & 6,7 & 34,2 & 16,2 & 7,1 & 4,1 \\
\hline Ireland & 22,8 & 23,3 & 23,1 & 30,8 & 31,6 & 11,5 & 16,8 & 6,0 & 20,1 & 12,6 & 1,4 \\
\hline Israel & 32,7 & 31,3 & 31,3 & 34,9 & 19,8 & 9,9 & 16,6 & 10,3 & 24,1 & 13,7 & 5,6 \\
\hline Italy & 42,4 & 42,6 & 43,1 & 40,6 & 25,8 & 5,0 & 30,1 & 6,6 & 14,4 & 13,8 & 4,4 \\
\hline Japan & - & 30,6 & 30,6 & 25,8 & 18,6 & 12,0 & 40,4 & 8,3 & 13,3 & 7,1 & 0,3 \\
\hline Korea & 26,9 & 26,2 & 25,2 & 21,5 & 17,6 & 13,6 & 26,2 & 11,6 & 15,8 & 12,3 & 2,9 \\
\hline Latvia & 30,4 & 30,4 & 29,2 & 29,1 & 21,0 & 5,6 & 27,3 & 3,5 & 26,8 & 15,1 & 0,7 \\
\hline Lithuania & 29,8 & 29,8 & 28,9 & 30,8 & 13,4 & 5,4 & 40,8 & 1,1 & 26,2 & 12,2 & 0,8 \\
\hline Luxembourg & 38,7 & 38,1 & 37,1 & 36,9 & 24,7 & 12,2 & 28,5 & 9,3 & 16,7 & 8,5 & 0,3 \\
\hline Mexico & 16,2 & 16,6 & 15,9 & 11,5 & 20,4 & 21,0 & 13,0 & 1,9 & 23,7 & 15,1 & 5,0 \\
\hline Netherlands & 38,8 & 38,4 & 37,0 & 36,9 & 18,5 & 8,7 & 38,2 & 4,0 & 17,6 & 11,9 & 1,1 \\
\hline New Zealand & 32,0 & 31,6 & 31,6 & 32,5 & 36,8 & 15,5 & 0,0 & 6,1 & 29,8 & 8,5 & 3,2 \\
\hline Norway & 38,2 & 38,7 & 38,4 & 41,9 & 27,6 & 10,4 & 27,4 & 3,3 & 22,3 & 9,1 & 0,0 \\
\hline Poland & 33,9 & 33,4 & 32,4 & 32,9 & 14,5 & 5,5 & 38,1 & 4,1 & 21,1 & 15,3 & 1,4 \\
\hline Portugal & 34,7 & 34,3 & 34,4 & 31,1 & 19,8 & 8,9 & 26,6 & 3,7 & 24,8 & 14,8 & 1,4 \\
\hline Slovak Republic & 32,9 & 32,4 & 32,2 & 33,6 & 10,2 & 10,8 & 43,5 & 1,3 & 20,6 & 12,4 & 1,2 \\
\hline
\end{tabular}




\begin{tabular}{|l|c|c|c|c|c|c|c|c|c|c|c|}
\hline Slovenia & 36,0 & 36,5 & 36,4 & 36,6 & 14,4 & 4,4 & 39,7 & 1,7 & 22,5 & 16,8 & 0,5 \\
\hline Spain & 33,7 & 33,2 & 33,6 & 33,2 & 21,4 & 6,8 & 34,2 & 7,7 & 19,1 & 10,3 & 0,5 \\
\hline Sweden & 44,0 & 44,0 & 43,1 & 49,0 & 29,8 & 6,2 & 22,6 & 2,4 & 20,9 & 7,2 \\
\hline Switzerland & 28,5 & 27,8 & 27,6 & 27,6 & 31,0 & 11,3 & 24,3 & 7,3 & 12,2 & 9,2 \\
\hline Turkey & 24,9 & 25,3 & 25,1 & 23,6 & 14,6 & 6,5 & 28,8 & 4,8 & 19,8 & 23,8 \\
\hline United Kingdom & 33,3 & 32,7 & 32,2 & 32,9 & 27,4 & 8,3 & 18,9 & 12,6 & 20,8 & 11,5 \\
\hline United States & 27,1 & 25,9 & 26,2 & 28,2 & 40,3 & 7,6 & 24,0 & 11,1 & 0,0 & 16,9 \\
\hline max & 46,2 & 51,6 & 46,1 & 49 & 53,5 & 21 & 43,5 & 34,2 & 41,2 & 23,8 & 0,5 \\
\hline min & 16,2 & 16,6 & 15,9 & 11,5 & 8,8 & 4,4 & 0,1 & 0,8 & 0 & 7,1 \\
\hline swing of variation & 30 & 35 & 30,2 & 37,5 & 44,7 & 16,6 & 43,4 & 33,4 & 41,2 & 16,7 \\
\hline average value & 34,5 & 34,5 & 33,7 & 33,8 & 23,5 & 9,0 & 27,7 & 6,4 & 20,0 & 12,4 & 2,5 \\
\hline
\end{tabular}

Source: Data from Revenue Statistics (2018)

The highest specific weight in the average structure of tax revenues of OECD countries in 2016 belongs to: social security contributions $(27,7 \%)$; taxes on income, individuals $(23,5 \%)$, value added taxes $(20 \%)$ and other consumption taxes $(12,4 \%)$. The following countries have, respectively, considerably higher shares as for the specified taxes: Slovak Republic (43,5\%), Denmark (53,5\%), Chile (41,2\%), Turkey (23,8\%). At the average share of corporate taxes in the amount of 9,0\%, it was $21,0 \%$ in Mexico. Specific weight of the taxes on property in Iceland (34,2\%) is by 5.34 times higher than the average indicator $(6,4 \%)$.

In the process of the European economic integration, the EU member states faced the negative impact of the existing fiscal mechanisms on the economic security due to their differentiation and in view of the intensified tax competition. Hence, the decisive actions to preserve the domestic fiscal standards, although still insufficient to ensure full unification of the respective regulations. From the standpoint of eliminating the threats to the economic safety of the European Union in the member states, state management of the fiscal system is increasingly relying on the concept of congruence and alignment of interests of all the participants in the fiscal process, i.e. the state, taxpayers and bearers of tax (natural and legal persons). Positive outcomes of such policy include elimination of the criminal schemes of shadow economy, VAT reimbursement, decreased contraband supply of excisable goods etc.

European governments are currently engaged in the struggle with tax havens, which lead to unfair tax competition (Teather 2002). In this context, the Internet is perceived as a tax haven, which enables economic agents to avoid payment of taxes on sale-purchase of goods through Internet shopping, because sellers (households and small sellers) are not required to declare their business activity and are exempted from taxes, including VAT (Beauvallet 2018). The article of Bikas et al. (2017) analyses the impact of VAT revenues on the EU Member States budgets (Bulgaria, Italy, Ireland and Lithuania), and the dynamics of the standard VAT rate and income from VAT collection efficiency. Imperfect legal regulation of e-commerce in this context leads to the loss of budget revenues (fiscal leakages). But if we consider cross-border purchases, it can be stated that Internet technologies contribute to the fight against evasion from tax payment, as they bring the sales tax in accordance with the location of a consumer.

Taxation of incomes of non-residents has an important influence of the tax security of a country (Eckhardjaneba 2001). When it has a non-discriminative character, in the equilibrium state, the international portfolio capital due to the mobility of motion quite successfully evades taxation even in the legal plane. If the countries agree upon the decision on setting the tax rates, the absence of discrimination encourages tax competition and leads to less evasion from tax payment. The advantage of the purpose-oriented principle is the considerations of effectiveness of distribution, because the purpose-oriented tax is neutral in terms of relative prices. The openness of the borders in the economic associations allows moving away from the principle of goods origin, but its use is simpler and allows the countries to expand the tax base, and to ensure convergence of tax rates. That is why small countries prefer the taxation by origin, and large countries - taxation by destination. In 2015, the European Union passed from the principle of origin to the purpose-oriented principle and set the VAT rate for the sale of e-services in the EU at the level of rate of a consumer country. However, in practice, 
the European countries received the right to set the marginal magnitude of agreements, the volume of sales that exceeds it makes the seller an entity of taxation of the goods in the destination country. For the agreements, the amounts of which are less than the marginal magnitude, the origin-based tax is applied. The implementation of this right is beneficial for large European countries, since taxation based on the purpose-oriented principle expands their tax base, but at the same time complicates the system of taxes coordination and contributes to decreasing tax competition.

\section{6 . Assessment of external and internal threats to tax security of Ukraine in the conditions of European integration}

The threats to the tax security of the national economy are divided into external and internal. The external threats are related to low competitiveness of the tax system of Ukraine in terms of an increase in the level of openness of its economy. The internal threats include corruption, which affects the efficiency of the tax administration; ineffectiveness of the state tax policies; considerable intensity of shadow processes in the economy. The shadow economy is the segment of the national economy, which is beyond the state control and accounting, and its assets, capital, business operations and financial results fall out of the scope of taxation objects in the legal field of the state.

The national economy of Ukraine is characterized by a high level of shadow economy (Fig. 1).

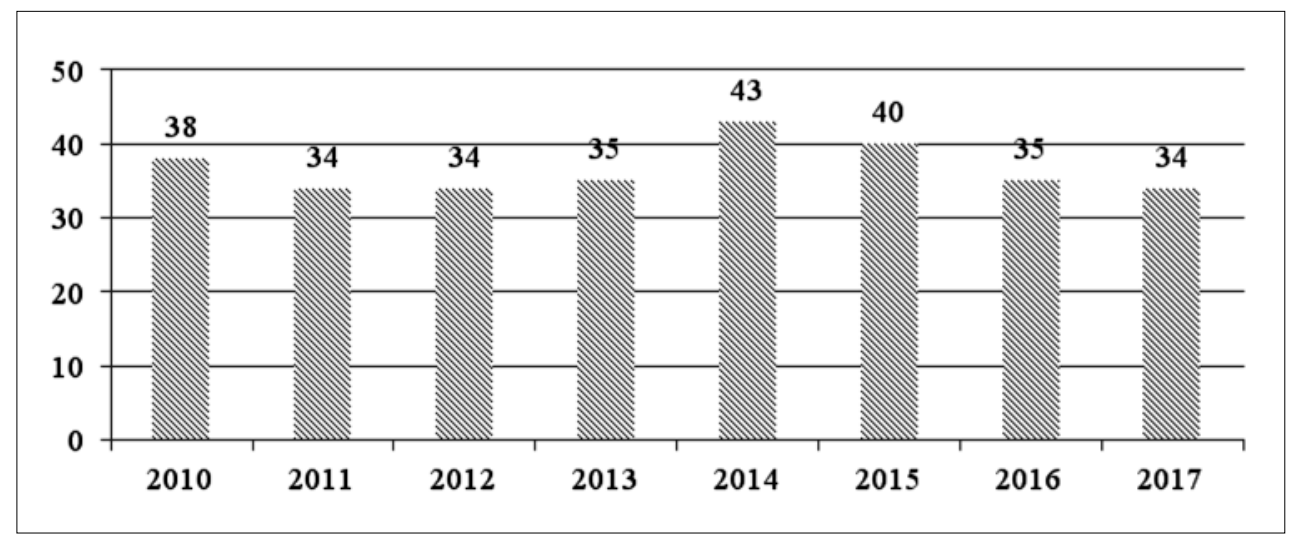

Figure 1. Integral indicator of the shadow economy level in Ukraine (in\% of official GDP)

Source: Ministry of Economic Development and Trade of Ukraine (2018)

The maximum value of the integral shadow economy level in Ukraine was observed in 2014(43\%), the minimumin 2011, 2012, 2017 (34\%). To calculate it, the following methods are used: "expenditures of the population retail trade turnover", the method of company's losses, electric method, and the monetary method. Reasons for the existence of the shadow economy include its considerable dollarization; macroeconomic instability; inefficiency of the processes of economy reforming; their lack of investment support; the instability of the legal field and unpredictable changes in the tax law; negative business and inflation expectations; the existence of the territories, formed during the military aggression on the territory of the country, which are uncontrollable by the government; unfavorable economic conditions for domestic exporters; critical dependence on imports of important commodity groups; a high level of corruption; low efficiency of functioning of the bodies of the judicial system; inadequate protection of property rights (movable and non-movable property), including the rights for financial assets. The shadow economy is a threat to the national security, because it distorts the mechanisms of action of market laws and tools, de-stimulates economic development, affecting negatively the formation of the financial resources of the public sector and the level of official employment, etc. The article of Giriūnienè et al. (2015) analyses the concept of tax system in terms of entrepreneurship promotion given the fact that more and more attention is recently paid to entrepreneurship and promotion of it precisely through the national tax system. Tax system is one of the economic entities' operating conditions enabling to promote or suppress entrepreneurship in the country; both self-employed persons and companies can be entrepreneurial 
entities; in any case, a state, in promoting or suppressing their entrepreneurship, thus, influences the national economy and its changes. The process of de-shadowing of economy will be facilitated by the creation of the institutional conditions for the growth of economic activity of economic entities in the legal economy through the improvement of the investment and business climate (Ohotina et al. 2018) in the country; as well as the improvement of the processes of tax collection and administration, transformation of the state fiscal service into the modern and efficient service body (Luzgina, 2017; Osipov et al. 2018).

In a market economy the activity of subjects involved in financial relationship is accompanied by various risks: financial, economic, technological, institutional, social, political. The tax gaps are defined as the difference between the amount of taxes which should be paid, and the amount of taxes that is actually paid. The main goal for application of the tax gaps concept is to evaluate the main fireats to the taxation base (Voronkova et al. 2016). The calculation of potential theoretical amount of paid taxes is based on the level o f economic energies and includes the assumption that all taxpayers fulfill their obligations in accordance with law. The gross tax gap allows assessing the amount of unpaid taxes as a result of tax evasion. The net tax gap is the amount of the gross tax gap minus the amounts levied by the results of control and supervision activity of the relevant authorities. The disbalance of the budget-debt relationships is a substantial threat to the national economy. Within 1993-2017, the consolidated budgets of Ukraine are chronically deficit, with the exception of 2000 and 2002 (Table 2-4).

Table 2. Consolidated budgets of Ukraine in 1993-2001, mln UAH

\begin{tabular}{|c|c|c|c|c|c|c|c|c|c|}
\hline Indicator & 1993 & 1994 & 1995 & 1996 & 1997 & 1998 & 1999 & 2000 & 2001 \\
\hline Revenue & 496,2 & 5230,9 & 20689,9 & 30218,7 & 28112,0 & 28915,8 & 32876,4 & 49117,9 & 54934,6 \\
\hline Expenditure & 572,5 & 6306,5 & 24302,8 & 34182,8 & 34312,7 & 31007,2 & 34714,2 & 48251,2 & 55413,7 \\
\hline Net lending & & & & & & 188,5 & 106,7 & $-102,6$ & 114,3 \\
\hline Deficit “-”/surplus “+” & $-76,3$ & $-1075,5$ & $-3612,9$ & $-3964,1$ & $-6200,7$ & $-2279,9$ & $-1944,5$ & 969,3 & $-593,4$ \\
\hline Ratio of deficit and budget revenues, $\%$ & $-15,38$ & $-20,56$ & $-17,46$ & $-13,12$ & $-22,06$ & $-7,88$ & $-5,91$ & 1,97 & $-1,08$ \\
\hline
\end{tabular}

Source: Ministry of Finance of Ukraine (2017)

Table 3. Consolidated budgets of Ukraine in 2002-2010, mln UAH

\begin{tabular}{|l|c|c|c|c|c|c|c|c|}
\hline \multicolumn{1}{|c|}{ Indicator } & 2002 & 2003 & 2004 & 2005 & 2006 & 2007 & 2008 & 2009 \\
\hline Revenue & 61954,3 & 75285,8 & 91529,4 & 134183,2 & 171811,5 & 219936,5 & 297893,0 & 272967,0 \\
\hline Expenditure & 60489,6 & 75430,1 & 101415,5 & 141698,8 & 175284,3 & 226054,4 & 309203,7 & 307399,4 \\
\hline Net lending & $-170,6$ & 362,4 & 1122,9 & 290,7 & 227,9 & 1583,8 & 2813,8 & 2825,8 \\
\hline Deficit “-"/surplus "+" & 1635,3 & $-506,7$ & $-11009,0$ & $-7806,3$ & $-3700,8$ & $-7701,7$ & $-14124,5$ & $-37258,1$ \\
\hline Ratio of deficit and budget revenues, \% & 2,64 & $-0,67$ & $-12,03$ & $-5,82$ & $-2,15$ & $-3,50$ & $-4,74$ & $-13,65$ \\
\hline
\end{tabular}

Source: Ministry of Finance of Ukraine (2017)

Table 4. Consolidated budgets of Ukraine in 2011-2017, mln UAH

\begin{tabular}{|l|c|c|c|c|c|c|c|c|}
\hline \multicolumn{1}{|c|}{ Indicator } & 2010 & 2011 & 2012 & 2013 & 2014 & 2015 & 2016 & 2017 \\
\hline Revenue & 314506,3 & 398553,6 & 445525,3 & 442788,7 & 456067,3 & 652031,0 & 782859,5 & 1016969,5 \\
\hline Expenditure & 377842,8 & 416853,6 & 492454,7 & 505843,8 & 523125,7 & 679871,4 & 835832,1 & 1056973,1 \\
\hline Net lending & 1348,4 & 4757,9 & 3856,3 & 535,2 & 4972,1 & 3057,8 & 1841,3 & 2122,1 \\
\hline Deficit “-"/surplus “+” & $-64684,9$ & $-23057,9$ & $-50785,7$ & $-63590,3$ & $-72030,5$ & $-30898,2$ & $-54813,9$ & $-42125,7$ \\
\hline Ratio of deficit and budget revenues, \% & $-20,57$ & $-5,79$ & $-11,40$ & $-14,36$ & $-15,79$ & $-4,74$ & $-7,00$ & $-4,14$ \\
\hline
\end{tabular}


Depending on the trajectory of the budget deficit, it is possible to distinguish the following stages, which have common characteristics (Fig. 2-4): a description with the parabola with upward branches and clearly expressed critical points, which represent the highest level of tax insecurity of the national economy: 1993-2001 (the maximum deficit of $6200.7 \mathrm{mln}$ UAH in 1997), 2002-2006 (the maximum deficit of $11009.0 \mathrm{mln}$ UAH in 2004), 2007-2017 (critical points of 2010 (-64684.9 mln UAH) and 2014 (-72030.5 mln UAH).

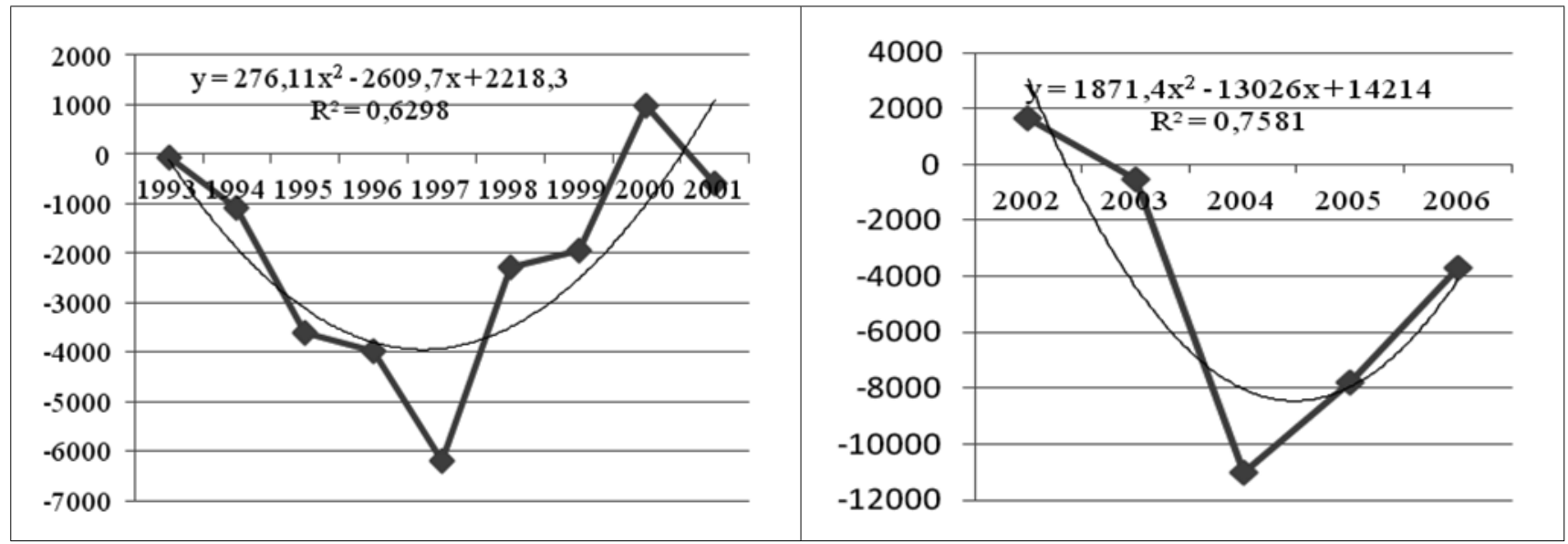

Figure 2. The deficit dynamics of Consolidated budgets of Ukraine in 1993-2001, mln UAH

Source: own calculations
Figure 3. The deficit dynamics of Consolidated budgets of Ukraine in 2002-2006, mln UAH

Source: own calculations

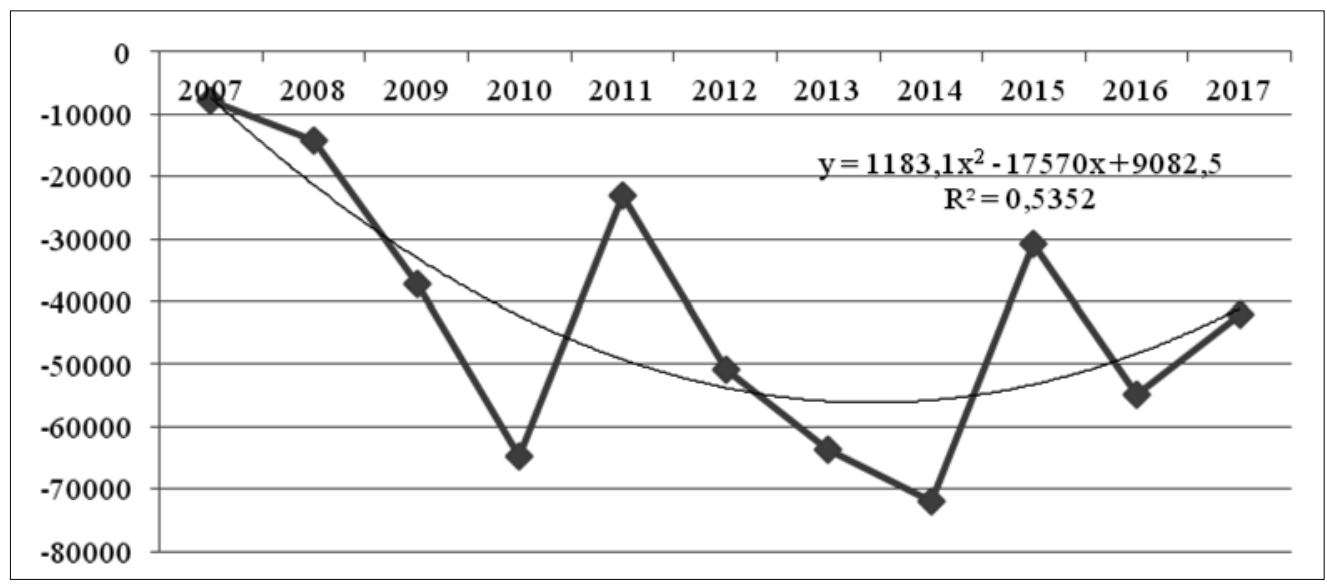

Figure 4. The deficit dynamics of Consolidated budgets of Ukraine in 2007-2071, mln UAH

Source: own calculations

Conventional indicators of budget deficit, calculated as the ratio to the total revenues of consolidated budget, have a different dynamics (Fig. 5-6). 


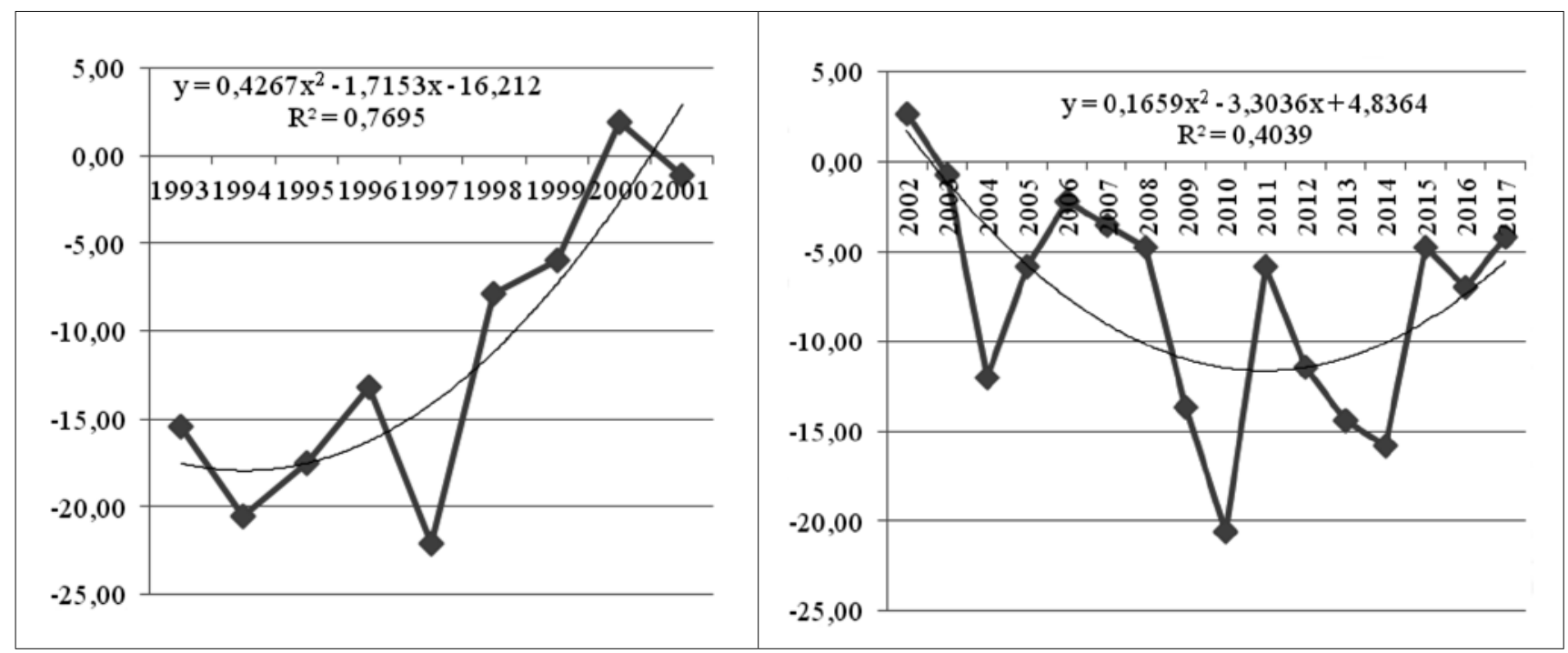

Figure 5. The dynamics of the ratio of deficit and budget revenues in 1993-2001, \%

Figure 6. The dynamics of the ratio of deficit and budget revenues in 2002-2017, \%

Source: own calculations

Source: own calculations

Within 1993-2001 the dynamics of the relative indicator of the deficit of the consolidated budget is described by the ascending branch of second-degree polynomial with the largest negative value in $1997(-22,06 \%)$ and the largest positive value in $2000(1.97 \%)$. in 2003, the ascending dynamics was replaced by the descending dynamics, which lasted until 2010. In 2002, the budget surplus level was 2, 4\%, in 2010 the relative budget deficit increased up to $20.57 \%$ of its income. At the ascending trend, the budget deficit level in 2017 decreased to $4,14 \%$.

One of the ways to reduce the deficit of the consolidated budget of Ukraine as a unitary state is to strengthen local finances (Kosova et al. 2015). Fiscal federalism is the world-renowned model of the public sector economy and reflects the complexity of the relationship between budgets of different levels. The main task is to determine the optimal level of centralization or decentralization of budget funds in the revenue part of the local budget.

\section{Conclusions}

The theoretical and methodological principles of researching the tax security of the state based on the theories of social choice and reflectivity were substantiated in the article. Taxes are considered as the payment for using the social benefits and the guarantee of national security. Tax security was described with a pair of recursive functions - the influence function and the cognitive function.

The differential features of national tax systems in the conditions of globalization and their impact on the economic security of the countries that differ in political regime, the level of economic development, geographical location, etc. were identified. The cross-sector approach, based on which multifactor effective marginal tax rates in the European Union (EU) are calculated, and the marginal approach to taxation in general were assessed.

Based on the analytical study of the tax security of the countries of the Organization of economic cooperation and development (OECD), it was found that social security contributions; taxes on income, individuals; value added taxes have the largest specific weight in the average structure of tax revenues. The special attention was paid to the problem of taxation of capital and goods movement between the EU countries in the framework of ensuring the mutual economic benefits and collective interests. The conclusion about the transition from the origin-based principle to the purpose-oriented principle in levying VAT in foreign trade operations was made. 
The assessment of the external and internal threats to the tax security of Ukraine was carried out based on the identification of the shadow economy segment, the reasons for its occurrence and consequences for the national economy, as well as the dynamics of absolute and relative indicators of the budget-debt security. Recommendations for strengthening the tax security under conditions of European integration were made.

An important pre-requisite of guaranteed safety of the national economy is sufficiency of the budget income to ensure functioning of the state and provide socially useful benefits to the citizens on a proper level. To that end, the fiscal policy of Ukraine needs to be transformed, in order to meet the requirements of fiscal convergence, which represents alignment, complementarity, compromise and stabilization of interests of the stakeholders in the fiscal process. The new institutional model of national economic safety is expected to fill the gaps in the fiscal policy that prevent effective functioning of the state, and ensure verification of its basic provisions.

The prospect of the subsequent research may be the agreement of the tax-budget and debt policy of the state in the context of strengthening their economic security.

\section{References}

Afanasyeva, L., Tkacheva, T. (2016). Comparative approach to the tax security assessment. Economic Annals-XXI, 157(3-4(1)), 106-108, http://dx.doi.org/10.21003/ea.V157-0033

Astrauskaite, I.; Paškevičius, A. (2016). Assessing the optimal taxation of the capital income: a case of corporate bond market, Journal of Security and Sustainability Issues 5(4), 519-532. https://doi.org/10.9770/jssi.2016.5.4(6)

Ball, N. (2014). Security and Economy in the Third World (Princeton Legacy Library), Princeton University Press, 462 p. ISBN-10: 0691606765, ISBN-13: 978-0691606767.

Barrios, S., Nicodème, G., Fuentes, A. Jesüs (2018). Multi-Factor Effective Corporate Taxation, Firms' Mark-Ups and Tax Incidence: Evidence from OECD Countries. Fiscal Studies. The Journal of Applied Public Economics, 39(3), 417-453. https://doi.Org/10.1111 /j.1475-5890.2017.12153

Beauvallet, M. (2018). Tax competition, tax coordination, and e-commerce. Journal of Public Economic Theory. Special Issue on Taxation in the Digital Economy 20(Special Issue 1), 100-117. https://doi.org/10.1111/jpet.12254

Bhandari, A., Evans, D., Golosov, M., Sargent Thomas, J. (2017). Fiscal Policy and Debt Management with Incomplete Markets. The Quarterly Journal of Economics, 132(2), 617-663, https://doi.org/10.1093/

Bikas, E., Bagotyrius, G., Jakubauskaite, A. (2017). The impact of value-added tax on the fiscal sustainability. Journal of Security and Sustainability Issues, 7(2): 267-285. https://doi.org/10.9770/jssi.2017.7.2(8)

Dobrovič, J.; Gombár, M.; Benková, E. (2017). Sustainable development activities aimed at combating tax evasion in Slovakia. Journal of Security and Sustainability Issues, 6(4), 761-772. https://doi.org/10.9770/jssi.2017.6.4(19)

Dube, G. (2014). Informal sector tax administration in Zimbabwe. Public administration and development. 34(1), 48-62. https://doi. org/10.1002/pad.1673

Eckhardjaneba, W. P. (2001). Tax Evasion, Tax Competition and the Gains From Nondiscrimination: the Case of Interest Taxation in Europe. The Economic Journal, 109(452), 93-101, https://doi.org/10.1111/1468-0297.00393

Fabuš, M.; Csabay, M. 2018. State aid and investment: case of Slovakia. Entrepreneurship and Sustainability Issues, 6(2), 480-488 https://doi.org/10.9770/jesi.2018.6.2(1)

Garcia, M., \& Haldenwang, C. (2016). Do Democracies Tax More? Political Regime Type and Taxation. Journal of International Development. 28(4), 485-506. https://doi.org/10.1002/jid.3078

Giriūnienè, G., Giriūnas, L. (2015). Sustainable development and tax system: it's impact on entrepreneurship. Journal of Security and Sustainability Issues, 4(3), 233-240. http://doi.org/10.9770/jssi.2015.4.3(4)

Hammar, H., Jagers Sverker, C., Nordblom, K. (2009). Attitudes towards Tax Levels: A Multi-Tax Comparison. Fiscal Studies. The Journal of Applied Public Economics, 29(4), 523-543. https://doi.org/10.1111/j.1475-5890.2008.00084.x

Haughton, J., Quan, N., Bao, Nguyen Hoang (2006). Tax Incidence in Vietnam. Asian Economic Journal. Journal of the East Asian 
Economic Association. 20(2), 217-239 https://doi.Org/10.1111/j.1467-8381.2006.00231.x

Heim, Bradley T. (2008). The effect of recent tax changes on taxable income: Evidence from a new panel of tax returns. Journal of Policy Analysis and Management, 28( 1), 147-163. https://doi.org/10.1002/pam.20406

Jun, A., Gallagher, D., Partington, G. (2011). Institutional Dividend Clienteles Under an Imputation Tax System. JBFA. Journal of Business Finance \& Accounting, 38(1-2), 198-224. https://doi.org/10.1111/j.1468-5957.2010.02214.x

Jung, K., Kim, Boyoung, Kim, Byungmo (2009). Tax Motivated Income Shifting and Korean Business Groups (Chaebol). JBFA. Journal of Business Finance \& Accounting, 36(5-6), 552-586. https://doi.org/10.1111/j.1468-5957.2009.02141.x

Kosova, T., Steblianko, I. (2015). Budget decentralization as a direction of structural reforms in the national economy, Scientific Bulletin of the Donbas State Machine-Building Academy, 2 (17E), 251-256.

Lipkova, L., Gress, M., Poncarova, A. (2017). Tax systems in the Czech Republic and the Slovak Republic: comparison with an emphasis on income tax. Economic Annals-XXI, 165(5-6), 47-51. https://doi.org/10.21003/ea.V165-10

Luzgina, A. (2017). Problems of corruption and tax evasion in construction sector in Belarus, Entrepreneurship and Sustainability Issues, 5(2), 263-282. http://doi.org/10.9770/jesi.2017.5.2(8)

Menshikov, V.; Volkova, O.; Stukalo, N.; Simakhova, A. (2017). Social economy as a tool to ensure national security, Journal of Security and Sustainability Issues 7(2): 211-231. https://doi.org/10.9770/jssi.2017.7.2(4).

Mertens, K., Montiel, O. José Luis (2018). Marginal Tax Rates and Income: New Time Series Evidence. The Quarterly Journal of Economics, 133, 4, 1803-1884, https://doi.org/10.1093/qje/qjy008

Mihokova, L., Andrejovska, A., Martinkova, S. (2016). Categorization of corporate taxation in the European Union countries using cluster analysis: a comparative study. Economic Annals-XXI, 160(7-8), 4-8. https://doi.org/10.21003/ea.V160-01

Ministry of Economic Development and Trade of Ukraine (2018), General trends of shadow economy in Ukraine. Available on the Internethttps://bit.ly/2BMCYJ1:

Ministry of Finance of Ukraine (2017), Statistical yearbook “Budget of Ukraine - 2017". Available on the Internet: https://www.minfin. gov.ua/uploads/redactor/files/Budget\%20of\%20Ukraine\%202017\%20(publish).pdf

Nellen, A. (2012). Internet Taxation and Principles of Good Tax Policy. Policy \& Internet, 4(1), 1-21. https://doi.org/10.1515/19442866.1152

Ohotina, A., Lavrinenko, O., Gladevich, J., Lazdans, D. (2018). The investment climate in Latvia's, Lithuania's and Belarus's crossborder regions: the subjective-objective assessment, Entrepreneurship and Sustainability Issues, 6(2), 767-780. http://doi.org/10.9770/ jesi.2018.6.2(20)

Onyshko, S., Novitskaya, O. (2004). Tax Component of Ukraine's Economic Security. Scientific Bulletin of the National Academy of State Tax Administration of Ukraine,. 5, 10-14.

Osipov, G.V., Glotov, V.I., Karepova, S.G. (2018). Population in the shadow market: petty corruption and unpaid taxes, Entrepreneurship and Sustainability Issues, 6(2), 692-710. http://doi.org/10.9770/jesi.2018.6.2(16)

Paseková, M., Müllerová, L., Svitáková, B. (2018). Impact of reporting of deferred tax on sustainable development of a counry: Case of Czech Republic, Journal of Security and Sustainability Issues, 7(4), 769-779. http://doi.org/10.9770/jssi.2018.7.4(13)

Petrenko, L. M. (2012). Tax Security as a Component of State Financial Security. Modeling and Information Systems in Economics, 86, pp. 89-98.

Piketty, T., Saez, E., Zucman, G. (2018). Distributional National Accounts: Methods and Estimates for the United States. The Quarterly Journal of Economics, 133(2), 553-609 https://doi.org/10.1093/qje/qjx043

Prichard, W. (2010). Taxation and State Building: Towards a Governance Focused Tax Reform Agenda. Journal of Theoretical Social Psychology. 341, 01-55 https://doi.Org/10.1111/j.2040-0209.2010.00341_2.x

Revenue Statistics (2018). Tax revenue trends in the OECD. Available on the Internet: https://www.oecd.org/tax/tax-policy/revenuestatistics-highlights-brochure.pdf

Santoro, A. (2007). Marginal Commodity Tax Reforms: a Survey. Journal of Economic Survey. 21(4), 827-848. https://doi.org/10.1111/ j.1467-6419.2007.00521.x 
Sevryukova, L., Belousova, S. (2016). Trends in taxation of personal income: Russian and foreign experience. Economic Annals-XXI, 157(3-4(1)), 41-43. http://dx.doi.org/10.21003/ea.V157-0012

Soros, G. (2015). The Alchemy of Finance, 2nd Ed., Published by John Wiley \& Sons. Inc., Hoboken. New Jersey, 176 p. ISBN: 978-0$471-44549-4$

Tarasova, V.I., Mezdrykov, Y. V., Efimova, S.B., Fedotova, E.S., Dudenkov, D. A., Skachkova, R.V. 2018. Methodological provision for the assessment of audit risk during the audit of tax reporting. Enterpreneurship and Sustainability Issues, 6(1), 371-397. http://doi. org/10.9770/jesi.2018.6.1(23)

Teather, R. (2002). Harmful Tax Competitions? Economic Affairs. The University of Buckingham, 22(4), 58-63. https://oi. org/10.1111/1468-0270.00385

Voronkova O., Kosova T. (2016). Macroeconomic modeling of tax gaps and elasticity of tax revenues: Ukrainian realities, Modern science, 2, 46-51.

Tvaronavičienè, M; Gatautis, R. (2017). Peculiarities of income distribution in selected countries. Economics and Sociology, 10(4), 113123. https://doi.org/10.14254/2071-789X.2017/10-4/9

Vandina, O., Mkrtychan, Z., Denisov, I., Vechkinzova, Y. (2018). The tax mechanism of managing the process of formation of information economy in modern Russia. Entrepreneurship and Sustainability Issues, 6(2): 830-839. https://doi.org/10.9770/jesi.2018.6.2(24)

\section{About contributors:}

Tetiana KOSOVA is Doctor of Economic Sciences, Professor, Professor of Department of Finance and Banking of Donetsk National University of Economics and Trade named after Mykhaylo Tugan-Baranovskiy. Research interests: mechanism of national economics; investment; finance, money circulation and credit; financial security.

ORCID ID: http://orcid.org/0000-0002-1859-0542

Iryna STEBLIANKO is Doctor of Economic Sciences, Associate Professor, Head of Department of Economics and Management of National Economy of Oles Honchar Dnipro National University. Research interests: mechanism of national economics, economic and social development, security substantial development and green economy.

ORCID ID: https://orcid.org/0000-0001-8103-1404

Nataliya SLOBODYANYUK is Doctor of Economic Sciences, Associate Professor, Head of Department of Finance and Banking of Donetsk National University of Economics and Trade named after Mykhaylo Tugan-Baranovskiy. Research interests: mechanism of national economics; investment and innovation; finance and banking; financial security.

ORCID ID: https://orcid.org/0000-0002-0803-9423

Vadym DOROSHKEVYCH is the Postgraduate Student of Department of Economics and Management of National Economy of Oles Honchar Dnipro National University. Research interests: mechanisms of state regulation of economic security of the national economy ORCID ID: https://orcid.org/0000-0003-1529-4155 